\title{
OTIONOMICS
}

Revista d'economia, empresa i societat

Dossier «Vectors of sustainability: visions from the economy»

Coordinator: Albert Puig Gómez

HOW CAN WE MANAGE AN ECONOMY WITHOUT GROWTH?

\section{Degrowth: a proposal to foster a deeply radical socio-ecological transformation}

\section{Federico Demaria}

Universitat de Barcelona

\begin{abstract}
For a sustainable post-Covid-19 recovery strategy, humanity faces two major challenges: 1. Just prosperity: The creation of a resilient and fair economy that delivers prosperity for all; 2. Public and planetary health: protect human health, together with the reduction of environmental impacts below thresholds of planetary boundaries including greenhouse gas emissions. The Covid-19 crisis could represent an opportunity for responses that integrate different goals, or a drawback if some are prioritized without considering their impacts on the others. New kinds of informed solutions are needed to ensure long-term sustainability in social, economic, and environmental terms. This article addresses the research question: How could developed countries manage a sustainable recovery that provides a good life for all within public and planetary health? First, it argues that economic growth is not compatible with environmental sustainability. Green Keynesianism is based on the hypothesis that economic growth can be decoupled from environmental impacts, but this has not happened and it is unlikely to happen. Second, it introduces degrowth as an alternative to green growth. Degrowth challenges the hegemony of economic growth and calls for a democratically led redistributive downscaling of production and consumption in industrialised countries as a means to achieve environmental sustainability, social justice, and well-being. Third, it traces the recent evolution of the term degrowth from an activist slogan to an academic concept. Last, it calls for an alliance of alternatives that could foster a deeply radical socio-ecological transformation.
\end{abstract}

KEYWORDS ecological economics; political ecology; post-growth; Europe; green growth; sustainable recovery

\section{Decreixement: una proposta per fomentar una transformació socioecológica profundament radical}

RESUM Per a una estratègia de recuperació sostenible post-Covid-19, la humanitat s'enfronta a dos grans desafiaments: 1. Prosperitat justa: La creació d'una economia resiliente i justa que ofereixi prosperitat per a tots; 2. Salut pública i planetària: protegir la salut humana, juntament amb la reducció dels impactes ambientals per sota dels llindars dels límits planetaris, incloses les emissions de gasos d'efecte hivernacle. La crisi del Covid-19 podria representar una 
oportunitat per a respostes que integrin diferents objectius, o un inconvenient si es prioritzen alguns sense considerar els seus impactes en els altres. Es necessiten nous tipus de solucions informades per garantir la sostenibilitat a llarg termini en termes socials, econòmics i ambientals. Aquest article aborda la qüestió de recerca: Com podrien els països desenvolupats gestionar una recuperació sostenible que proporcioni una bona vida per a tots dins de la salut pública $i$ planetària? En primer Iloc, argumenta que el creixement econòmic no és compatible amb la sostenibilitat ambiental. El keynesianismo verd es basa en la hipòtesi que el creixement econòmic pot desacoblar-se dels impactes ambientals, però això no ha succeït i és poc probable que succeeixi. En segon lloc, introdueix el decreixement com una alternativa al creixement verd. El decreixement desafia l'hegemonia del creixement econòmic i exigeix una reducció redistributiva democràticament dirigida de la producció i el consum als països industrialitzats com un mitjà per aconseguir la sostenibilitat ambiental, la justícia social i el benestar. En tercer lloc, traça l'evolució recent del terme decreixement, d'un eslògan activista a un concepte acadèmic. Finalment, demana una aliança d'alternatives que puguin fomentar una transformació socioecológica profundament radical.

PARAULES CLAU economia ecològica; ecologia política; post-creixement; Europa; creixement verd; recuperació sostenible

\section{Why is economic growth incompatible with environmental sustainability?}

"Growth for the sake of growth" remains the credo of all governments and international institutions, including the European Commission. Economic growth is presented as the panacea that can solve any of the world problems: poverty, inequality, sustainability, etc. You name it. Left-wing and right-wing policies only differ on how to achieve it. However, there is an uncomfortable scientific truth that must be faced: Economic growth is environmentally unsustainable. Moreover, beyond a certain threshold already surpassed by EU countries, socially it is not necessary. The central question then becomes: How can we manage an economy without growth? In this article, I explain what is degrowth, and how it has evolved from an activist slogan to an academic concept.

Economist Kenneth Boulding famously said that: "Anyone who believes that exponential growth can go on forever in a finite world is either a madman or an economist". Ecological economists argue that the economy is physical, while mainstream economists seem to believe it is metaphysical. Social metabolism is the study of material and energy flows within the economy. On the input side of the economy, key material resources are limited, and many are peaking including oil and phosphorus. On the output side, humanity is trespassing planetary boundaries. Climate change is the evidence of the limited assimilative capacity of ecosystems. It is the planet saying: "Enough is enough!".

Mainstream economists, finally convinced by the existence of biophysical limits, started to argue that economic growth can be decoupled from the consumption of energy and materials (or from environmental impacts, that is the same thing). Historical data series (like Material Flow Accounting from EUROSTAT) demonstrate that this, so far, has not happened. At most, there is relative decoupling (a decrease in resource use per unit of GDP). But there is no absolute decoupling, that is what matters for sustainability: an absolute decrease of environmental resources consumption. The only periods of absolute dematerialisation coincide with economic recession. Trade should also be taken into account, to avoid externalisation of pollution intensive activities outside the EU (the so-called pollution haven hypothesis).

The current economy cannot be circular. The main reason being that energy cannot be recycled, and materials only up to a certain extent. The global economy recycles less than $10 \%$ of materials; about $50 \%$ of processed materials are used to provide energy and are thus not available for recycling (they are basically fossil fuels). It is simple: economic growth is not compatible with environmental sustainability. The list of nice oxymorons is long (from sustainable development to its reincarnations like green economy or green growth), but wishful thinking does not solve real problems. Increase in GDP leads to increase in material and energy use, and therefore to environmental unsustainability.

Technology and market-based solutions are not magic bullets. Faith in technology has become religious: scientific evidence shows that, based on past trends in technological improvement, these are coming way too slowly to avoid irreversible climate change. For instance, efficiency improvements lead to rebound effects, in the context of economic growth (the more efficient you are, the more you consume; e.g., cars and petrol consumption). Renewable energy 
produces less net energy, because it has a lower EROI (Energy Return on Investment) than fossil fuels. For this and for other reasons, it cannot satisfy current levels of energy consumption, which therefore needs to be reduced. Most of the world's fossil fuel reserves must be left in the ground, unburned, to keep global temperature rise to no more than $2^{\circ} \mathrm{C}$. In fact, fossil fuels should be called unburnable fuels.

Science sometimes brings bad news. An article recently published in Nature Sustainability argues that: "No country in the world meets the basic needs of its citizens at a globally sustainable level of resource use" (O'Neill et al., 2018). The question then is: how can the conditions for a good life for all within planetary boundaries be generated?

The uncomfortable truth to be faced by policy makers is the following:

- Economic growth is ecologically unsustainable. The total consumption of materials and energy needs to be reduced, starting from developed countries.

- Economic growth might also not be socially desirable. Inequalities are on the rise; poverty has not been eliminated and life satisfaction is stagnant.

- Economic growth is fuelled by debt (e.g., quantitative easing), which corresponds to a colonisation of the future. This debt cannot be paid, and the financial system is prone to instability (despite Basilea III).

For instance, scientifically is not clear how the European Union will achieve a low-carbon economy in a context of economic growth, since it implies a reduction of greenhouse gas emissions to $80 \%$ below 1990 levels by 2050. In fact, climatologists Kevin Anderson and Alice Bows have argued convincingly that: "for a reasonable probability of avoiding the $2^{\circ} \mathrm{C}$ characterisation of dangerous climate change, the wealthier (Annex 1) nations need, temporarily, to adopt a degrowth strategy".

Obviously, a transition from a growth society to a de-growth (or post-growth) one poses several challenges. However, the emerging field of ecological macroeconomics is starting to address them convincingly. Happiness and economics literature shows that GDP growth is not needed for well-being, because there are other important determinants (see Easterlin paradox). High life expectancy is compatible with low carbon emissions, but high incomes are not. Moreover, lack of growth may increase inequalities unless there is redistribution.

In any case, the issue is not whether we shall abandon economic growth. The question is how. Scientific debates around it are on the rise, but I am afraid policy making is behind. There are good signs: critiques of GDP as an indicator of well-being are common, there are policy proposals and degrowth is entering into the parliaments. This is not new. For example, in 1972 Sicco Mansholt, a Dutch social-democrat who was then EU Commissioner for agriculture, wrote a letter to the President of EU Commission Franco Maria Malfatti, urging him to seriously take into account limits to growth in the EU economic policy. Mansholt himself became President of the European Commission after only two months, but for a too short term to push a zero (or below) growth agenda. The time is ripe not only for a scientific degrowth research agenda, but also for a political one. As ecological economists Tim Jackson and Peter Victor argued in The New York Times: "Imagining a world without growth is among the most vital and urgent tasks for society to engage in".

\section{Defining degrowth}

Generally, degrowth challenges the hegemony of economic growth and calls for a democratically led redistributive downscaling of production and consumption in industrialised countries as a means to achieve environmental sustainability, social justice and well-being (Demaria et al., 2013). Degrowth is usually associated with the idea that smaller can be beautiful. However, the emphasis should not only be on less, but also on different. In a degrowth society everything will be different: activities, forms and uses of energy, relations, gender roles, allocations of time between paid and nonpaid work, relations with the non-human world.

The point of degrowth is to escape from a society that is absorbed by the fetishism of growth. Such a rupture is therefore related to both words and things, the symbolic and the material practices. It implies the decolonisation of the imaginary and the implementation of other possible worlds. The degrowth project does not aim for another growth, nor for another kind of development (sustainable, social, fair, etc.), but rather for the construction of another society, a society of frugal abundance (Latouche), a post-growth society (Niko Paech), eco-feminist degrowth (Perez-Orozco), or one of prosperity without growth (Tim Jackson). In other words, it is not an economic project from the outset, not 
even of another economy, but a societal project that implies escaping from the economy as a reality and as imperialist discourse. 'Sharing', 'simplicity', 'conviviality', 'care' and the 'commons' are primary significations of what this society might look like (D’Alisa et al., 2015).

Although integrating bio-economics and ecological macroeconomics, degrowth is a non-economic concept. On one side, degrowth certainly implies the reduction of the social metabolism (the energy and material throughput of the economy), needed in order to face the existing biophysical constraints (in terms of natural resources and ecosystem's assimilative capacity). On the other side, degrowth is an attempt to challenge the omnipresence of market-based relations in society and the growth-based roots of the social imaginary replacing them by the idea of frugal abundance. It is also a call for deeper democracy, applied to issues which lie outside the mainstream democratic domain, like technology. Finally, degrowth implies an equitable redistribution of wealth within and across the Global North and South, as well as between present and future generations.

Over the last couple of decades, the face of the triumph of a single-thought ideology of growth has been no other than the seemingly consensual "sustainable development" slogan, a nice oxymoron. Its aim was to try to save the religion of economic growth in the ecological crisis which seemed to be well accepted by the anti-globalisation movement. It became urgent to oppose the capitalism of a globalised market with another civilisational project or, more specifically, to give visibility to a plan that had been in formation for a long time, but progressed underground. The rupture with developmentalism, a form of productivism for the use of so-called developing countries, was thus the foundation of this alternative project.

The term degrowth was proposed by political ecologist André Gorz in 1972 and was used to entitle a book with the French translation of Nicholas Georgescu Roegen's essays in 1979. Degrowth was then launched by French environmental activists in 2001 as a provocative slogan to repoliticise environmentalism. The motto of degrowth was almost accidentally launched by a pressing need to break with the doublespeak, often meaninglessness, of sustainable development that was felt by whole streams of political ecology and development critics. Thus, the phrase is not originally a concept (at least not symmetrically to economic growth) but rather a defiant political slogan with the main objective of reminding us of the meaning of limits; more specifically, degrowth is neither recession nor negative growth. The word should not be interpreted literally: degrowing to degrow would be as absurd as growing to grow.

A degrowth transition is not a sustained trajectory of descent, but a transition to convivial societies who live simply, in common and with less. There are several ideas about the practices and institutions that can facilitate such a transition and the processes that can bring them together and allow them to flourish. The attractiveness of degrowth emerges from its power to draw from and articulate different sources or streams of thought (including justice, democracy and ecology) and to formulate strategies at different levels (including oppositional activism, grassroots alternatives and institutional politics). It brings together a heterogeneous group of actors who focus on different issues, from agroecology to climate justice. Degrowth could complement and reinforce these topic areas, functioning as a connecting thread (i.e., a platform for a network of networks) beyond one-issue politics.

In fact, Degrowth is not the alternative, but rather a matrix of alternatives that reopens the human adventure to a plurality of destinies and the space of creativity, by lifting the lead blanket of economic totalitarianism. This is about exiting the paradigm of homo œconomicus or Marcuse's one-dimensional man, the main source of planetary homogenisation and the murder of cultures. Consequently, the degrowth society will not be established the same way in Europe, in sub-Saharan Africa or in Latin America, in Texas and in Chiapas, in Senegal and in Portugal. It is crucial to favour or rediscover diversity and pluralism. It is therefore not possible to formulate 'turnkey' solutions for degrowth, but only to outline the fundamentals of any non-productivist sustainable society and concrete examples of transitional programmes. The design can take the form of a "virtuous circle" of sobriety in the form of 8 'R's: re-evaluate, reconceptualise, restructure, relocate, redistribute, reduce, reuse and recycle (Latouche, 2009). These eight interdependent objectives constitute a revolutionary rupture, which can trigger a dynamic towards an autonomous society of sustainable and convivial sobriety.

The politics of this historical dynamic - the actors, alliances, institutions and social processes creating degrowth transitions remains the subject of a lively debate in Europe and beyond. For instance, in September 2018 over 200 scientists wrote an open letter to the major European institutions entitled 'Europe, it is time to end the growth dependency'; it was then signed by almost 100,000 citizens. The degrowth network includes over 100 organisations with 3,000 active members, mostly located in Europe but also in South and North America, the Philippines, India, Tunisia and Turkey. 


\section{Recent evolution of the term: from an activist slogan to an academic concept}

In 2023, we celebrate the 15th anniversary of the first international degrowth conference in Paris. This event introduced the activist slogan décroissance, of French origin, into the English-speaking world and international academia as degrowth. I want to take stock of the last decade in terms of conferences, publications, training and more recently policy making. I am focusing only on the academic achievements in English, leaving aside both activism and intellectual debates in other languages - these are huge, especially in French, Spanish, Italian and German.

\subsection{International conferences}

The academic collective Research \& Degrowth (R\&D) aims at the facilitation of networking and the flow of ideas between various actors working on degrowth, especially in academia. For this reason - as well as in order to increase the visibility of the degrowth ideas and proposals in the public space - R\&D has organised the 1st (Paris 2008) and 2nd (Barcelona 2010) conferences, and called with a Support Group for the 3rd (Venice and Montreal 2012), 4th (Leipzig 2014), 5th (Budapest), 6th (Malmo, Mexico City, and European parliament 2018), 7th (Manchester, 2020), 8th (The Hague, 2021), 9th (Pontevedra, 2023) ones. Apart from demonstrating the latest research in the field, the conferences aim at promoting cooperative research and work in the formulation and development of research and political proposals. Many other conferences and workshops have taken place. For instance, the conferences of the European Society for Ecological Economics (ESEE) - Istanbul 2011, Lille 2013, Leeds 2015, Budapest 2017, Turku 2019, Pisa 2022 - have been important to advance the debate and the society has endorsed the degrowth conferences since Paris 2008.

\subsection{Academic publications}

In 2008 there were only a couple of published papers in English on degrowth (Latouche, 2004 and Fournier, 2008). I have lost count, but today there are probably over 400 published papers, 15 special issues and 20 books (for a review see Weiss and Cattaneo, 2017; and Kallis et al., 2018). The Media Library at degrowth.info aims to collect them all. Lately, there have been also articles on degrowth in prestigious journals like Nature Sustainability (O'Neill et al., 2018), Nature Communications (Wiedmann, 2020), and Nature Energy (Hickel, 2021).

We might be witnessing the emergence of a new scientific paradigm, in the sense of "universally recognised scientific achievements that, for a time, provide model problems and solutions for a community of researchers" (Kuhn, 1962: x). I believe the fifteen special issues have played an important role in proving the legitimacy of the research questions raised by degrowth as an academic concept. There has been a first wave of generalist special issues (Schneider et al., 2010; Cattaneo et al., 2012; Saed, 2012; Kallis et al., 2012; Sekulova et al., 2013; Whitehead, 2013; Kosoy, 2013; Asara et al., 2015). More recently, we have entered into a second wave on specific themes (Technology and Degrowth by Kerschner et al., 2018; Tourism and Degrowth by Fletcher et al., 2019; Environmental Justice and Degrowth by Akbulut et al., 2020; Blue degrowth and the politics of the sea by Ertör and Hadjimichael, 2020; Degrowth and Planning by Xue et al., 2022; Urbanization and degrowth by Kaika et al., 2022) or that introduce degrowth to a new discipline (i.e., Anthropology: Degrowth, Culture and Power by Gezon and Paulson, 2017; Geography: Geographies of degrowth by Demaria et al., 2019; Organization studies: Degrowth and organizations by Banerjee et al., 2021).

The book Degrowth: A Vocabulary for a New Era (Routledge, 2014) has been translated into more than ten languages. Others have recently been published (e.g., Bonaiuti, 2011; Kallis, 2017, 2018; Borowy and Schmelzer, 2017; Nelson and Schneider, 2018; Alexander and Gleeson, 2019; Chertkovskaya et al., 2019; Liegey and Nelson, 2020; Kallis et al., 2020; Hickel, 2020; Burkhart et al., 2020). 


\subsection{Training}

The youth participating in the degrowth conferences presented a need for training opportunities. The summer school in Barcelona on degrowth and environmental justice has reached its eighth edition (summerschool.degrowth.org). A more activism-oriented one is regularly organised at climate camps in Germany. In 2021 I organised an online summer crash course on Ecological and feminist macroeconomics at the University of Barcelona with over 300 students. Degrowth is taught in many university courses, and at the Autonomous University of Barcelona we launched a master's degree in 'Political ecology, degrowth and environmental justice' in 2018, and another online master 'Degrowth: Ecology, Economics and Policy' in 2021 (see master.degrowth.org). Our Degrowth Reading Group in Barcelona has been running for over 10 years, and many more exist around the world.

\subsection{Policy making}

I have argued elsewhere that degrowth is entering into the parliaments (The Ecologist, 16th January 2017). Some political parties have started to adopt degrowth oriented or degrowth compatible proposals in their political programs. At the House of Commons in London there is an 'All-Party Parliamentary Group (AAPG) on limits to growth'. In 2018, a seminar was hosted at the European Commission titled "Well-being beyond GDP growth?", and a post-growth conference at the European Parliament to challenge the economic thinking of EU institutions with influential EU policy makers. The emerging field of ecological macroeconomics is shedding some light on policy related challenges (Victor, 2008; Rezai and Stagl, 2016; Jackson, 2017; Hardt and O'Neill, 2017). Many questions remain open: Can degrowth enter the Parliaments? How large would its constituency be? What policy proposals shall be put forward? How could a synergy be built between grassroots social movements and institutional politics? For how long will we keep sacrificing everything in the name of growth? How far will the mainstream be able to support growth's mirage? And how - and who - is going to challenge the discontent emerging out of slow growth in growth's societies? Can we give this frustration a new meaning and direction, other than that of closure and phobia? Welcome to the new era of post-growth politics.

\subsection{The future: a blank canvas}

The future is a blank canvas. We need to think of objectives, strategies and priorities. Let me mention something that I think is fundamental. There is a need to strengthen the relationships with close research and activist communities like the ones of feminisms, environmental justice, political ecology, ecological economics, post-extractivism, anti-racism, commons, decoloniality, and post-development. An interesting precedent is the project Degrowth in movement(s) (Burkhart et al., 2020) that explores the relationships with over 30 different perspectives. There is also the FaDA: Feminisms and Degrowth Alliance. Inspired by our book Pluriverse: A Post-Development Dictionary (Kothari et al., 2019) and along the lines of the Indian experience Vikalp Sangam (Hindi for 'Confluence of Alternatives'), scholars and activists launched the Global Tapestry of Alternatives (GTA) that seeks to build bridges between networks of transformative alternatives around the globe and promote the creation of new processes of confluence. Degrowth is in fact just one among many other alternatives. The 'how' needs to be thought through - e.g., a joint visioning process - but the 'why' is clear. The alliances among these networks, and networks of networks, are fundamental to weave the alternatives and foster a deeply radical socio-ecological transformation. We could imagine it as a rhizome of resistance and regeneration. 


\section{References}

D'ALISA, G.; DEMARIA, F.; KALLIS, G. (2015). Degrowth: A Vocabulary for a New Era [online]. London: Routledge. Available at: https://vocabulary.degrowth.org. DOl: https://doi.org/10.4324/9780203796146

DEMARIA, F.; SCHNEIDER, F; SEKULOVA, F.; MARTINEZ-ALIER, J. (2013). "What is degrowth? From an activist slogan to a social movement”. In: Environmental values, vol. 22, no. 2, pp. 191-215 [online]. DOl: https://doi.org/10.3197/ $096327113 \times 13581561725194$

KALLIS, G.; PAULSON, S.; D’ALISA, G.; DEMARIA, F. (2020). The case for degrowth. Cambridge: Polity Press.

KOTHARI, A.; SALLEH, A.; ESCOBAR, A.; DEMARIA, F.; ACOSTA, A. (eds.) (2019). Pluriverse: A Post-Development Dictionary. Delhi, India: Authors Up Front / Tulika / Columbia University Press.

LATOUCHE, S. (2009). Farewell to Growth. Cambridge: Polity.

\section{Resources}

Research \& Degrowth (R\&D) is an academic association that promotes biannual international conferences, summer schools and a Master's degree. www. degrowth.org

The degrowth blog: https://www.degrowth.info/en/blog/

World mailing list: http://www.criticalmanagement.org/node/3220

Recommended citation: DEMARIA, Federico. Degrowth: a proposal to foster a deeply radical socio-ecological transformation. Oikonomics [online]. November 2021, n. 16. ISSN: 2339-9546. DOI: https://doi.org/10.7238/o.n16.2111

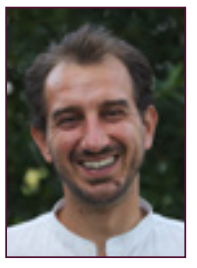

\section{Federico Demaria}

federico.demaria@ub.edu

Universitat de Barcelona

He is a Serra Hunter assistant professor in ecological economics and political ecology at the Universitat de Barcelona, a researcher at the Institute of Environmental Science and Technology at UAB, and a member of Research \& Degrowth. He is also an editor of the journal Sustainability Science, and an expert reviewer for the IPCC. He is the co-editor of two successful books: Degrowth (2014) and Pluriverse (2019), as well as co-author of "The case for degrowth" (Polity Press, 2020).

The texts published in this journal are - unless otherwise indicated - covered by the Creative Commons Spain Attribution 4.0 International licence. Each article may thus be copied, distributed, communicated to the public and used as the basis for derivative works, provided that its author, the journal and its publishing institution are credited as specified by the author or journal. The full text of the licence can be consulted here: http://creativecommons.org/licenses/by/4.0/.

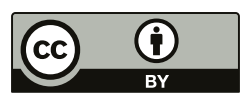

